\title{
Comparison of Leukotriene Receptor Antagonist and Theophylline in Addition to Inhaled Corticosteroid in Adult Asthma: A Meta-Analysis
}

\author{
Huijuan Fang ${ }^{1}$, Jianmiao Wang ${ }^{1}$, Di Jin ${ }^{2}$, Yong Cao ${ }^{1}$, Yongjian $\mathrm{Xu}^{1}$ and Weining Xiong ${ }^{1, *}$ \\ ${ }^{1}$ Department of Respiratory Diseases, Tongji Hospital, Key Lab of Pulmonary Diseases of Health Ministry, Tongji Medical College, \\ Huazhong University of Science and Technology, Wuhan 430-030, \\ ${ }^{2}$ Teaching and Research Division of Internal Medicine, Hubei College of Chinese Medicine, Jingzhou 434-020, China
}

\begin{abstract}
This meta-analysis was performed to evaluate the difference of the therapeutic efficacy and adverse effects of leukotriene receptor antagonist and theophylline added to inhaled corticosteroids in adult asthma. Databases were searched for studies published through Nov, 2010. Randomized-controlled trials containing inhaled corticosteroids plus leukotriene receptor antagonist and inhaled corticosteroids plus sustained-release theophylline for asthma therapy were selected. For each report, data were extracted to the outcomes analyzed: mean change in morning peak expiratory flow, mean change in evening peak expiratory flow, mean change in morning forced expiratory volume in $1 \mathrm{sec}$, mean change in daily short bete2-agonist use, asthma exacerbation and adverse effects. Four assessable trials including 182 asthmatic patients were identified. Inhaled corticosteroids plus leukotriene receptor antagonist was superior to inhaled corticosteroids plus theophylline therapy in improving morning peak expiratory flow in asthmatics (mean difference 19.08 [95\% confidence interval 13.37-23.79] l/min, $p<0.001$ ) and morning forced expiratory volume in $1 \mathrm{sec}$ in asthmatics (mean difference 0.09 [95\% confidence interval 0.03-0.14] liter, $p=0.001$ ). In evening peak expiratory flow, daily short bete2-agonist use, asthma exacerbation and adverse effects, there was no significant difference between these two therapies (All $p>0.05$ ). Our meta-analysis showed that the combination of inhaled corticosteroids plus leukotriene receptor antagonist resulted in more improvement in both peak expiratory flow and forced expiratory volume in 1 sec in the morning than inhaled corticosteroids plus sustained-release theophylline in adult asthmatics. Further trials are necessary to evaluate the dominant effects of the former combination.
\end{abstract}

Key Words: Asthma, Meta-analysis, Leukotriene receptor antagonist, Theophylline, Inhaled corticosteroids

\section{INTRODUCTION}

Asthma is a disorder of the intrapulmonary airways characterized by variable airflow obstruction and airway hyperresponsiveness to various environmental or inherent stimuli. In the majority of patients, mild to moderate asthma airway dysfunction is usually responsive to inhaled corticosteroids (ICS) that form the mainstay of therapy (Fanta, 2009). In fact, asthmatic symptoms are well controlled by ICS alone in many cases, but other patients with persistent asthma require additional medications.

At present, alternative controller medications include longacting $\beta_{2}$ agonists (LABA), leukotriene receptor antagonist (LTRA) and sustained-release theophylline. LABA significantly improve pulmonary function in patients with uncontrolled asthma as add-on therapy to ICS compared with LTRA and theophylline (Davies et al., 1998; Moore et al., 1998). Since LABA do not have definite anti-inflammatory effects, there are little concerns about enhancing airway remodeling by LABA (Vanacker et al., 2002). Further more, inhaled medicine may fail to reach small airways, the site of inflammation in moderate to severe asthmatic patients (Mcivor et al., 1998).

Both LTRA and theophylline have anti-inflammatory effects, and can reach the small airway via the bloodstream, so they may be also the suitable choice (Spina et al., 1998; Lipworth, 1999). In an early small randomized controlled trial (RCT), in patients who still have symptoms on treatment with ICS, the addition of LTRA or sustained-release theophylline to the treatment had similar results in benefits and adverse effects (Yurdakul et al., 2002). Since then, the comparison of www.biomolther.org

Open Access DOI: 10.4062/biomolther.2011.19.3.296

pISSN: 1976-9148 elSSN: 2005-4483

Copyright $\odot 2011$ The Korean Society of Applied Pharmacology
Received Sep 20, 2010 Revised Dec 31, 2010 Accepted Jan 23, 2011

\section{*Corresponding Author}

E-mail: xiongdoctor@hotmail.com

Tel: +86-27-8366-3617, Fax: +86-27-8366-2898 
LTRA and sustained-release theophylline in addition to ICS has been evaluated in several other RCTs, and the results were not very consistent. Thus, the objective of the present meta-analysis was to evaluate the difference of the therapeutic efficacy and adverse effects of LTRA and sustained-release theophylline added to ICS in asthma.

\section{MATERIALS AND METHODS}

\section{Data sources and searches}

Two investigators (Huijuan Fang and Di Jin) searched MEDLINE, EMBASE, LILACS, and CINAHL databases for relevant articles published until Nov, 2010, no lower date limit was applied. The first MEDLINE search strategy retrieved citations containing the "leukotriene receptor antagonist OR montelukast OR pranlukast OR zafirlukast" and "theophylline" and "inhaled corticosteroids" and "asthma*" (Limits Activated: Randomized Controlled Trial). We modified these searches for the other databases. We screened reference lists from all retrieved articles and from recent review articles to identify additional studies. There were no language restrictions. Results were double-checked and arbitrated by a second investigator (Weining Xiong).

\section{Study selection}

We included full-text publications that investigated adult patients with asthma during treatment with ICS, including LTRA or sustained-release theophylline as the second medications.

\section{Data extraction and quality assessment}

To avoid bias in the data-abstraction process, two observers independently abstracted information about participants, interventions, and comparisons from publications, including mean change in morning peak expiratory flow (PEF), mean change in evening PEF, mean change in morning forced expiratory volume in 1 second $\left(\mathrm{FEV}_{1}\right)$, mean change in daily short $\beta_{2}$-agonist use, asthma exacerbation and adverse effects. Another reviewer double-checked the information. In the dataabstraction process for each trial that we identified, if the trial had none of the relevant information mentioned above, then the trial was excluded from the analysis for that information. In addition, for each trial, data defined according to criteria that varied from that mentioned above also were considered no evaluable. All data were checked for internal consistency, and disagreements were resolved by discussion among the investigators.

We assessed the trials in terms of their risk of bias, according to the following domains: allocation of randomization sequence, concealment of allocation, blinding, handling of withdrawals, selective reporting, and other bias (such as inconsistencies in the baseline). Each entry is divided into yes, probably yes or no, but concealment of allocation is divided into yes, probably yes, unclear or no. Each of these quality domains was scored on a 3-point scale. Trials received an A score when all quality criteria for the domain were met, a $B$ score when the criteria were partially met, and a $\mathrm{C}$ score when the criteria were not met (Schulz et al., 1995; Jadad et al., 1996).

\section{Statistical analysis}

For outcomes where data are reported as binary event data, we have pooled studies with a fixed-effect risk ratio (RR). However, where studies have reported no events occurring and thus contribute zero event rates to analyses, we reported the risk differences, in addition to relative risk, to incorporate their estimates in the analysis. The proportions of patients with severe exacerbations from each trial were pooled by using the fixed-effects method expressed as a Peto odds ratio (OR) with corresponding 95\% confidence intervals (Cls) (DerSimonian

Table 1. The characteristics of subjects studied

\begin{tabular}{|c|c|c|c|c|c|}
\hline Study & Design/Methods & Participants & $\begin{array}{c}\text { Interventions } \\
\text { (addition to ICS) }\end{array}$ & $\begin{array}{l}\text { Duration of } \\
\text { trial, wks }\end{array}$ & Outcomes \\
\hline Yurdakul, 2002 & A randomized study & $\begin{array}{l}64 \text { patients with } \\
\text { moderate } \\
\text { persistent asthma }\end{array}$ & $\begin{array}{l}\text { Formoterol vs. } \\
\text { zafirlukast vs. } \\
\text { theophylline }\end{array}$ & $\begin{array}{c}4,8,12 \\
\text { (3 time point } \\
\text { and } 8 \text { chosen) }\end{array}$ & $\begin{array}{l}\text { Mean change in number of daily } \\
\text { short } \beta_{2} \text {-agonist use, asthma } \\
\text { exacerbation and adverse effects } \\
\text { others }\end{array}$ \\
\hline Dempsey, 2002 & $\begin{array}{l}\text { A randomized single-blind, } \\
\text { placebo controlled, double } \\
\text { dummy, three-way cross- } \\
\text { over study }\end{array}$ & $\begin{array}{l}24 \text { patients with } \\
\text { middle- moderate } \\
\text { persistent asthma }\end{array}$ & $\begin{array}{l}\text { High dose ICS } \\
\text { vs. zafirlukast } \\
\text { vs. theophylline }\end{array}$ & $\begin{array}{c}4 \\
\text { (one stage) }\end{array}$ & $\begin{array}{l}\text { Mean change in morning PEF, } \\
\text { mean change in evening PEF, mean } \\
\text { change in morning FEV } 1 \\
\text { others }\end{array}$ \\
\hline Tsuchida, 2005 & $\begin{array}{l}\text { A single blind, randomized, } \\
\text { multicenter study }\end{array}$ & $\begin{array}{l}67 \text { patients with } \\
\text { moderate or severe } \\
\text { persistent asthma }\end{array}$ & $\begin{array}{l}\text { Pranlukast vs. } \\
\text { theophylline }\end{array}$ & 4 & $\begin{array}{l}\text { Mean change in morning PEF, } \\
\text { mean change in evening PEF, mean } \\
\text { change in number of daily short } \beta_{2^{-}} \\
\text {agonist use } \\
\text { others }\end{array}$ \\
\hline Shah, 2006 & $\begin{array}{l}\text { A randomized, double- } \\
\text { blind study }\end{array}$ & $\begin{array}{l}90 \text { patients with } \\
\text { asthma }\end{array}$ & $\begin{array}{l}\text { High dose ICS } \\
\text { vs. Montelukast } \\
\text { vs. theophylline }\end{array}$ & 8 & $\begin{array}{l}\text { Mean change in morning } P E F \text {, mean } \\
\text { change in morning } \mathrm{FEV}_{1} \text {, mean } \\
\text { change in number of daily short } \beta_{2^{-}} \\
\text {agonist use, asthma exacerbation } \\
\text { others }\end{array}$ \\
\hline
\end{tabular}


and Laird, 1986).

For quantitative and continuous data variables we have calculated a fixed effect weighted mean difference (WMD) for data measured on the same scale. For data measured on different scales which could not be converted to a WMD, we have pooled using a fixed-effect standardized mean difference (SMD). Where possible, for each end point, we combined the results from individual studies to produce summary effect estimates. Heterogeneity was calculated with the Cochrane $Q$ statistic test and the $I^{2}$ test (Deeks et al., 2001; Higgins et al., 2003). Based on the statistical significance of heterogeneity test $(p>0.10)$, a fixed-effect model was applied in our metaanalysis (DerSimonian and Laird, 1986).

All analyses were conducted with Cochrane Review Manage 5.0.23 (Cochrane Library Software, Oxford, United Kingdom).

\section{RESULTS}

\section{Study characteristics and quality}

After independent review, four RCTs including the compari- son of LTRA and theophylline in addition to ICS in asthmatic adults were considered to be eligible for inclusion in the analysis (Dempsey et al., 2002; Yurdakul et al., 2002; Tsuchida et al., 2005; Shah et al., 2006), all available for analysis, and their characteristics are listed in Table 1. Totally, 90 patients were randomly assigned to LTRA addition to ICS and 92 patients were assigned to theophylline addition to ICS groups. As shown in Table 2, the quality scores of all these 4 studies were high, three studies reached $A$, and remaining one reached grade $B$.

\section{Outcomes}

Mean change in morning PEF (L/min): 143 patients from three studies were considered for this analysis ( 71 treated with ICS plus LTRA, 72 treated with ICS plus theophylline) (Dempsey et al., 2002; Tsuchida et al., 2005; Shah et al., 2006). ICS plus LTRA was superior to ICS plus theophylline therapy in improving morning PEF in asthmatics (mean difference 19.08 [95\% Cl 13.37-23.79] l/min, $p<0.001$ ) (Fig. 1). No significant inter-study heterogeneity was found $(R=0, p=0.58)$.

Mean change in evening PEF (L/min): 83 patients from two studies were considered for this analysis ( 41 treated with ICS

Table 2. Quality scores

\begin{tabular}{|c|c|c|c|c|c|c|c|c|}
\hline Study & $\begin{array}{c}\text { Adequate } \\
\text { sequence } \\
\text { generation }\end{array}$ & $\begin{array}{l}\text { Allocation con- } \\
\text { cealment }\end{array}$ & Blinding & $\begin{array}{c}\text { Incomplete } \\
\text { outcome data } \\
\text { addressed }\end{array}$ & $\begin{array}{c}\text { Baseline } \\
\text { characteristics }\end{array}$ & $\begin{array}{l}\text { Free of selective } \\
\text { reporting }\end{array}$ & $\begin{array}{c}\text { Free of } \\
\text { other bias }\end{array}$ & Grade \\
\hline Yurdakul, 2002 & Unclear & Unclear & Unclear & Yes & Yes & Yes & Yes & $B$ \\
\hline Dempsey, 2002 & Yes & Yes & Yes & Yes & Yes & Yes & Yes & $A$ \\
\hline Tsuchida, 2005 & Yes & Yes & Yes & Yes & Yes & Yes & Yes & $A$ \\
\hline Shah, 2006 & Yes & Yes & Yes & Yes & Yes & Yes & Yes & A \\
\hline
\end{tabular}

A Mean change in morning peak expiratory flow $(\mathrm{l} / \mathrm{min})$

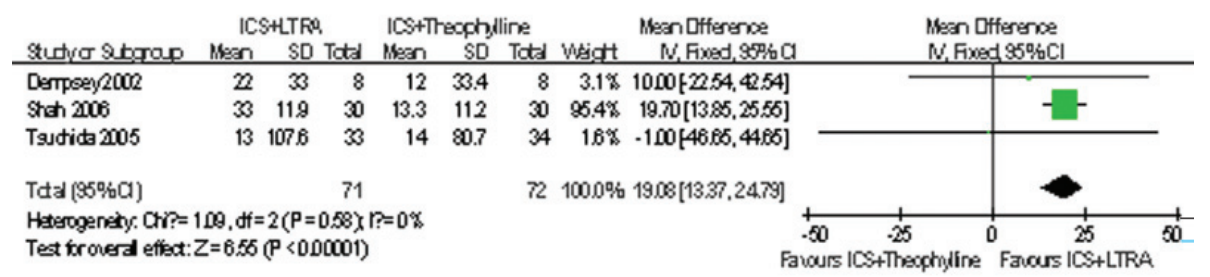

B Mean change in evening peak expiratory flow (l/min)

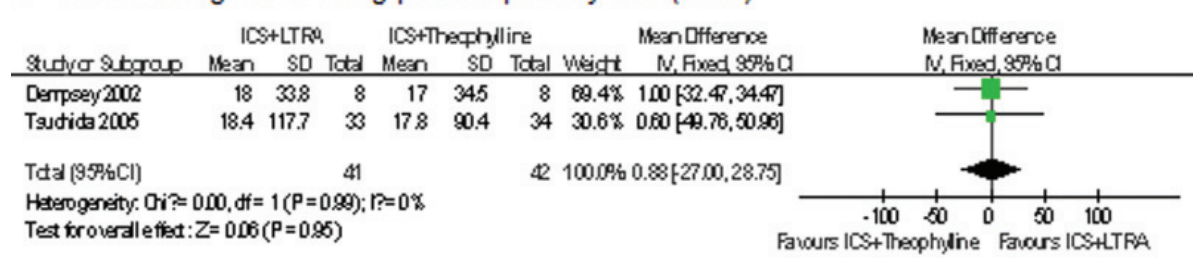

C Mean Change in morning forced expiratory volume in 1 second (liter)

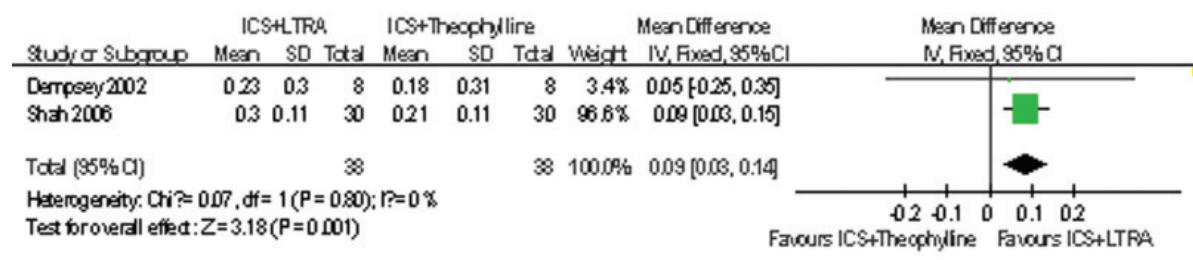

Fig. 1. Summary effect on mean change in morning peak expiratory flow (L/min), evening peak expiratory flow $(\mathrm{L} / \mathrm{min})$ and morning forced expiratory volume in 1 second (liter). ICS means inhaled corticosteroids, LTRA means leukotriene receptor antagonist. 
A Mean change in daily beta2-agonist use

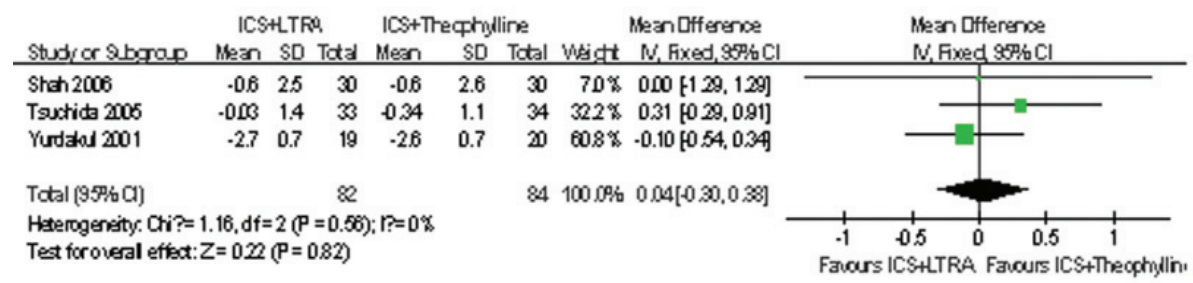

B Asthma exacerbation

\begin{tabular}{|c|c|c|c|c|c|c|c|c|}
\hline \multirow[b]{2}{*}{ 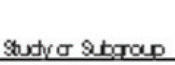 } & \multirow{2}{*}{\multicolumn{2}{|c|}{$\begin{array}{l}\text { ICS+LTRA } \\
\text { Eusts Tatal }\end{array}$}} & \multicolumn{2}{|c|}{ ICS+Theophylline } & & \multirow{2}{*}{ 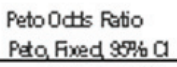 } & \multirow{2}{*}{\multicolumn{2}{|c|}{$\begin{array}{l}\text { Peto Odds Ratio } \\
\text { Peto, Fxed, } 95 \% \mathrm{Pl}\end{array}$}} \\
\hline & & & Eusts & Tdtal & mejgt & & & \\
\hline Shah 2006 & 4 & 30 & 4 & 30 & $1000 \%$ & 100 p23,438] & & \\
\hline Yuntelul 2001 & 0 & 19 & 0 & 20 & & Nat estimatle & & \\
\hline Tdtal ( $(\% \% \mathrm{Cl})$ & & 49 & & 50 & $100 \% \%$ & 1.00 [. 23,438$]$ & & \\
\hline Tota everts & 4 & & 4 & & & & & \\
\hline $\begin{array}{l}\text { Heterogenety Nbt ap } \\
\text { Test froverdl effect: }\end{array}$ & $\begin{array}{l}\text { dictle } \\
Z=000(P\end{array}$ & $=1 \omega 0$ & & & & & $\begin{array}{lll}001 & 0.1 & 1 \\
& & 1\end{array}$ & $\begin{array}{l}10 \\
\text { ICS+Theophyllin }\end{array}$ \\
\hline
\end{tabular}

\section{Adverse effects}

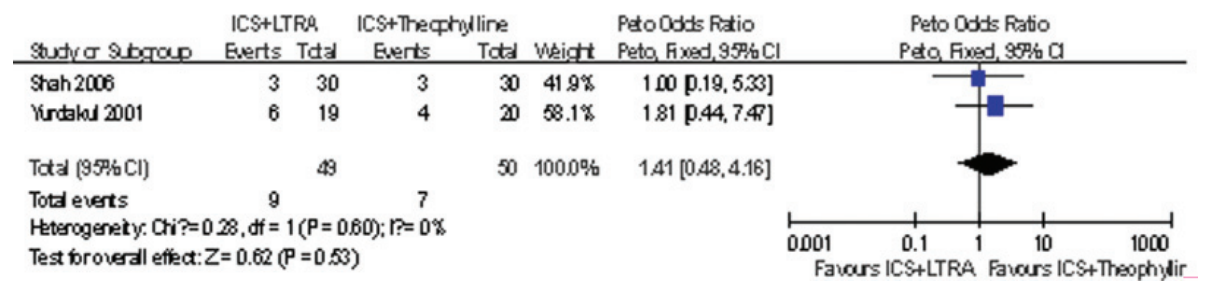

Fig. 2. Summary effect on mean change in daily beta2-agonist use, asthma exacerbation and adverse effects. ICS means inhaled corticosteroids, LTRA means leukotriene receptor antagonist. plus LTRA, 42 treated with ICS plus theophylline) (Dempsey et al., 2002; Tsuchida et al., 2005). There was no significant difference between ICS plus LTRA and ICS plus theophylline therapy in improving evening PEF in asthmatics (mean difference 0.88 [95\% Cl-27.00-28.75], $p=0.95$ ) (Fig. 1). No significant inter-study heterogeneity was found $\left(R^{2}=0, p=0.99\right)$.

Mean change in morning FEV $_{1}$ (liter): 76 patients from two studies were considered for this analysis (38 treated with ICS plus LTRA, 38 treated with ICS plus theophylline) (Dempsey et al., 2002; Shah et al., 2006). ICS plus LTRA was superior to ICS plus theophylline therapy in improving morning FEV in asthmatics (mean difference 0.09 [95\% Cl 0.03-0.14] liter, $p<0.001$ ) (Fig. 1). No significant inter-study heterogeneity was found $(R=0, p=0.80)$.

Mean change in number of daily short $\beta_{2}$-agonist use: 166 patients from three studies were considered for this analysis (82 treated with ICS plus LTRA, 84 treated with ICS plus theophylline) (Yurdakul et al., 2002; Tsuchida et al., 2005; Shah et al., 2006). There was no significant difference between ICS plus LTRA and ICS plus theophylline therapy in reducing the number of daily $\beta 2$-agonist use in asthmatics (mean difference 0.04 [95\% Cl -0.30-0.38], $p=0.82$ ) (Fig. 2). No significant interstudy heterogeneity was found $(R=0, p=0.56)$.

Asthma exacerbations: Data on asthma exacerbations were available in two trials (49 treated with ICS plus LTRA, 50 treated with ICS plus theophylline) (Yurdakul et al., 2002; Shah et al., 2006). Asthma exacerbations were almost equal between ICS plus LTRA and ICS plus theophylline therapy in asthmatics (pooled OR 1.00 [95\% Cl 0.23-4.38], $p=1.00$ ) (Fig. 2). The heterogeneity was not applicable.

Adverse effects: 99 patients from two studies were consid- ered for this analysis (49 treated with ICS plus LTRA, 50 treated with ICS plus theophylline) (Yurdakul et al., 2002; Shah et al., 2006). There was no major adverse reactions noted, and no significant difference between ICS plus LTRA and ICS plus theophylline therapy in minor adverse events in asthmatics (pooled OR 1.41 [95\% Cl 0.48-4.16], $p=0.53$ ) (Fig. 2). No significant inter-study heterogeneity was found $(R=0, p=0.60)$.

\section{DISCUSSION}

The objectives of effective asthma management are to prevent chronic or frequently recurring symptoms, to maintain normal pulmonary function and normal activity levels, to prevent recurrent acute exacerbations and avoid adverse effects from asthmatic medications (NIH, 2002). In some cases, especially in persistent asthma, these objectives are sometimes not fully fulfilled with ICS alone. For this purpose, in addition to ICS, we discussed the efficacy of the second controller medications in the treatment of asthma. Within the currently available add-on medications, LABA probably shows the strongest bronchodilator effects and is the first-line therapy in persistent asthma in combination with ICS $(\mathrm{NIH}, 2002)$. In asthmatic adults on low doses of ICS, the addition of LABA is superior to LTRA or theophylline for asthma control (Ducharme et al., 2006; Tee et al., 2007). However, LABA is not primarily an antiinflammatory drug, and does not appear to have any clinically important anti-inflammatory or proinflammatory effect (Sindi et al., 2009). Furthermore, the effect of LABA on airway remodeling remains controversial (Orsida et al., 2001; Vanacker et al., 2002). Thus, LTRA or theophylline as the add-on medication 
to ICS should be reconstructed.

It has been reported that add-on therapy with LTRA or theophylline to ICS significantly improved lung function and asthmatic symptoms in comparison with an increased dose of ICS (Evans et al., 1997; Price et al., 2003). Then, which add-on agent is better? In the current meta-analysis, we found that ICS plus LTRA therapy was superior to ICS plus theophylline therapy in improving morning PEF and $\mathrm{FEV}_{1}$, measures that are commonly used for quantifying asthma control. In other indexes, such as evening PEF, daily short $\beta_{2}$-agonist use, asthma exacerbation and adverse effects, there is not significant difference between these two therapies.

Owning to very limited studies were available for inclusion in this meta-analysis, we could not examine the effect of study quality on the main endpoints in the treatment of asthma with LTRA or theophylline. For the same reason, we could not investigate whether or not study size, agents (different LTRA or different ICS), or duration of treatment affect the evaluation of LTRA or theophylline. Because of inconsistent results reported among the trials, some comparisons had to be restricted to patients for whom results were available instead of using all patients. In our meta-analysis, although ICS plus LTRA therapy was superior to ICS plus theophylline therapy in improving morning PEF and FEV ${ }_{1}$, we could find that in the three studies included in the analysis for these two indexes, one study (Shah et al., 2006) had a too large weight caused by other two studies (Dempsey et al., 2002; Tsuchida et al., 2005) due to their excessive standard deviation. Thus, this conclusion should be regarded cautiously.

The trials included in this meta-analysis showed a wide variation in size or the treatment regimens used, and relative small sample size. We noted that different LTRA, such as montelukast, pranlukast, zafirlukast, were used in different studies and different ICS, such as budesonide and beclomethasone, were used in different studies, although they have similar efficacy. Fortunately, the inspection about heterogeneity indicated that the heterogeneity in our study did not reach the level of significance.

In conclusion, our meta-analysis showed that the combination of ICS plus LTRA resulted in more improvement in both PEF and FEV in the morning than ICS plus sustained-release theophylline in asthmatics, but in evening PEF, daily short $\beta_{2}-$ agonist use, asthma exacerbation and adverse effects, there was no significant difference between these two therapies. Based on the limits of this meta-analysis, we call for future works about the comparison of LTRA and sustained-release theophylline in addition to ICS in the form of larger, multicentre, randomized controlled trials adequately to evaluate this therapeutic option in patients with persistent asthma.

\section{ACKNOWLEDGMENTS}

This study was partly supported in part by research grants No. 30300144 and 30900647 from National Natural Science Foundation of China.

\section{REFERENCES}

Davies, B., Brooks, G. and Devoy, M. (1998) the efficacy and safety of salmeterol compared to theophylline: Meta-analysis of nine con- trolled studies. Respir. Med. 92, 256-263.

Deeks, J. J., Altman, D. and Bradburn, M. J. (2001) Statistical methods for examining heterogeneity and combining results from several studies in meta-analysis. In Systematic Reviews in Health Care (M. Egger, G. Davey Smith, D. G. Altman, Eds.), pp. 285-312. BMJ Publishing, Nondon, UK.

Dempsey, O. J., Fowler, S. J., Wilson, A., Kennedy, G. and Lipworth, B. J. (2002) Effects of adding either a leukotriene receptor antagonist or low-dose theophylline to a low or medium dose of inhaled corticosteroid in patients with persistent asthma. Chest 122, 151-159.

DerSimonian, R. and Laird, N. (1986) Meta-analysis in clinical trials Control. Clin. Trials. 7, 177-188.

Ducharme, F. M., Lasserson, T. J. and Cates, C. J. (2006) Long-acting beta2-agonists versus anti-leukotrienes as add-on therapy to inhaled corticosteroids for chronic asthma. Cochrane Database Syst. Rev. 18, CD003137.

Evans, D. J., Taylor, D. A., Zetterstrom, O., Chung, K. F., O'Connor, B. J. and Barnes, P. J. (1997) A comparison of low-dose inhaled budesonide plus theophylline and high-dose inhaled budesonide for moderate asthma. N. Engl. J. Med. 337, 1412-1418.

Fanta, C. H. (2009) Asthma. N. Engl. J. Med. 360, 1002-1014

Higgins, J. P., Thompson, S. G., Deeks, J. J. and Altman, D. G. (2003) Measuring inconsistency in meta-analyses. BMJ 327, 557-560.

Jadad, A. R., Moore, R. A., Carroll, D., Jenkinson, C., Reynolds, D. J., Gavaghan, D. J. and McQuay, H. J. (1996) Assessing the quality of reports of randomized clinical trials: is blinding necessary? Control. Clin. Trials 17, 1-12.

Lipworth, B. J. (1999) Leukotriene-receptor antagonist. Lancet. 353, 57-62.

Mcivor, R. A., Pizzichini, E., Turner, M. O., Hussack, P., Hargreave, F. E. and Sears, M. R. (1998) Potential masking effects of salmeterol on airway inflammation in asthma. Am. J. Respir. Crit. Care Med. 158, 924-930.

Moore, R. H., Khan, A. and Dickey, B. F. (1998) Long-acting inhaled beta2-agonists in asthma therapy. Chest 113, 1095-1108.

National Institutes of Health (NIH). (2002) National heart, lung, and blood institute. global initiative for asthma. NIH Publication, Bethesda, MD.

Orsida, B. E., Ward, C., Li, X., Bish, R., Wilson, J. W., Thien, F. and Walters, E. H. (2001) Effect of a long-acting-beta2-agonist over three months on airway remodeling in asthma. Am. J. Respir. Crit. Care Med. 164, 117-121.

Price, D. B., Hernandez, D., Magyar, P., Fiterman, J., Beeh, K. M., James, I. G., Konstantopoulos, S., Rojas, R., van Noord, J. A., Pons, M., Gilles, L., Leff, J. A.; Clinical Outcomes with Montelukast as a Partner Agent to Corticosteroid Therapy (COMPACT) International Study Group. (2003) Randomised controlled trial of montelukast plus inhaled budesonide versus double dose inhaled budesonide in adult patients with asthma. Thorax. 58, 211-216.

Schulz, K. F., Chalmers, I., Hayes, R. J. and Altman, D. G. (1995) Empirical evidence of bias. Dimensions of methodological quality associated with estimates of treatment effects in controlled trials. JAMA. 273, 408-412.

Shah, A. R., Sharples, L. D., Solanki, R. N. and Shah, K. V. (2006) Double-blind, randomised, controlled trial assessing controller medications in asthma. Respiration. 73, 449-456.

Sindi, A., Todd, D. C. and Nair, P. (2009). Antiinflammatory effects of long-acting beta2-agonists in patients with asthma: a systematic review and metaanalysis. Chest 136, 145-154.

Spina, D., Landells, L. J. and Page, C. P. (1998) The role of theophylline and phosphodiesterase 4 isoenzyme inhibitors as anti-inflammatory drugs. Clin. Exp. Allergy 28(suppl), 24-34.

Tee, A. K., Koh, M. S., Gibson, P. G., Lasserson, T. J., Wilson, A. J. and Irving, L. B. (2007) Long-acting beta2-agonists versus theophylline for maintenance treatment of asthma. Cochrane Database Syst. Rev. 18, CD001281.

Tsuchida, T., Matsuse, H., Machida, I., Kondo, Y., Saeki, S., Tomari, S., Obase, Y., Matsuo, N., Shimoda, T. and Kohno, S. (2005) Evaluation of theophylline or pranlukast, a cysteinyl leukotriene receptor 1 antagonist, as add-on therapy in uncontrolled asthmatic patients with a medium dose of inhaled corticosteroids. Allergy Asthma. Proc. 26, 287-291. 
Fang et al. LTRA versus Theophylline in Addition to ICS in Adult Asthma

Vanacker, N. J., Palmans, E., Pauwels, R. A. and Kips, J. C. (2002) Effect of combining salmeterol and fluticasone on the progress of airway remodeling. Am. J. Respir. Crit. Care Med. 166, 1128-1134. Yurdakul, A. S., Calişir, H. C., Tunçtan, B. and Ogretensoy, M. (2002)
Comparison of second controller medications in addition to inhaled corticosteroid in patients with moderate asthma. Respir. Med. 96, 322-329. 